\title{
Presence of Xylella fastidiosa in Sweet Orange Fruit and Seeds and Its Transmission to Seedlings
}

\author{
W.-B. Li, W. D. Pria, Jr., P. M. Lacava, X. Qin, and J. S. Hartung
}

First author: Fruit Laboratory, U.S. Department of Agriculture-Agricultural Research Service (USDA-ARS), Beltsville, MD 20705; second author: Department of Biochemistry, UNESP, Araraquara, SP, Brazil; third author: Graduate Program in Environmental Sciences, UNITAU, Taubaté, SP, Brazil; fourth author: Department of Dairy Science, University of Georgia, Athens; and fifth author: Fruit Laboratory, USDA-ARS, Beltsville, MD 20705.

Accepted for publication 10 March 2003.

\begin{abstract}
Li, W.-B, Pria, W. D., Jr., Lacava, P. M., Qin, X., and Hartung, J. S. 2003. Presence of Xylella fastidiosa in sweet orange fruit and seeds and its transmission to seedlings. Phytopathology 93:953-958.

Xylella fastidiosa, a xylem-limited bacterium, causes several economically important diseases in North, Central, and South America. These diseases are transmitted by sharpshooter insects, contaminated budwood, and natural root-grafts. $X$. fastidiosa extensively colonizes the xylem vessels of susceptible plants. Citrus fruit have a well-developed vascular system, which is continuous with the vascular system of the plant. Citrus seeds develop very prominent vascular bundles, which are attached through ovular and seed bundles to the xylem system of the fruit. Sweet orange (Citrus sinensis) fruit of cvs. Pera, Natal, and Valencia with characteristic symptoms of citrus variegated chlorosis disease were collected for analysis. X. fastidiosa was detected by polymerase chain

reaction (PCR) in all main fruit vascular bundles, as well as in the seed and in dissected seed parts. No visual abnormalities were observed in seeds infected with the bacterium. However, the embryos of the infected seeds weighed $25 \%$ less than those of healthy seeds, and their germination rate was lower than uninfected seeds. There were about 2,500 cells of $X$. fastidiosa per infected seed of sweet orange, as quantified using real-time PCR techniques. The identification of $X$. fastidios $a$ in the infected seeds was confirmed by cloning and sequencing the specific amplification product, obtained by standard PCR with specific primers. $X$. fastidiosa was also detected in and recovered from seedlings by isolation in vitro. Our results show that $X$. fastidiosa can infect and colonize fruit tissues including the seed. We also have shown that $X$. fastidiosa can be transmitted from seeds to seedlings of sweet orange. To our knowledge, this is the first report of the presence of $X$. fastidiosa in seeds and its transmission to seedlings.
\end{abstract}

Xylella fastidiosa Wells et al., a gram-negative and xylem-limited bacterium (33), causes numerous diseases on many economically important fruit and urban shade trees as well as grapevine (22). Citrus variegated chlorosis (CVC), a destructive disease of sweet orange, Citrus sinensis (L.) Osbeck, was first discovered in São Paulo, Brazil, in 1987 and subsequently was shown to be caused by novel strains of $X$. fastidiosa $(4,10,28)$. CVC disease can be transmitted by sharpshooter insects (family Cicadellidae) (26), contaminated plant budwood (13), and natural root grafts (11). CVC has rapidly spread to all citrus production areas in Brazil (2), reaching an average incidence of $35 \%$ in São Paulo State. A similar disease known as "pecosita" was found in some regions in Argentina (3). Although sweet orange trees affected by the disease do not die, fruit from the trees may be severely undersized, hard, and lacking juice. Such fruit is unacceptable for either the juice or fresh market.

The English language name for the citrus disease, CVC, comes from the striking chlorotic variegation induced on sweet orange leaves by the pathogen. However, the disease is also known as "amarelinho de citros" in Portuguese. This name roughly translates as "little yellow citrus" and emphasizes the importance of the fruit symptoms of the disease, which include premature coloration and failure to fill to normal size. Typical fruit symptoms of the disease can be easily recognized from a distance.

Corresponding author: J. S. Hartung; E-mail address: hartungj@ba.ars.usda.gov

Publication no. P-2003-0529-01R

This article is in the public domain and not copyrightable. It may be freely reprinted with customary crediting of the source. The American Phytopathological Society, 2003.
Because these fruit symptoms are easy for producers to recognize and it is the smaller fruit size that causes economic loss, most Brazilian citrus producers prefer the name amarelinho de citros for the disease.

The severity of the CVC disease problem contributed to the selection of a citrus strain of $X$. fastidiosa as the first plant-pathogenic bacterium to have its entire genome sequenced (31). The strain selected was 9a5c, obtained from CVC-infected sweet orange plants in Brazil $(4,15)$. Many important advances have been made in research using the citrus strains of $X$. fastidiosa, including improved pathogenicity tests, identification of alternate experimental hosts $(17,18)$, genetic transformation (24), and molecular methods for strain differentiation (25). Similar attention has been paid to the Pierce's disease strain $(9,12)$. At least some strains of $X$. fastidiosa, including the peach $(1,8)$ and citrus strains $(11)$, can colonize the entire vascular system of the plant, including the roots. However, the presence and distribution of the bacterium in fruit and seed has received little attention. In one report, sharpshooter insect vectors of $X$. fastidiosa were not able to transmit the pathogen after feeding on grape clusters harvested from vines with Pierce's disease. However, in this experiment, the bulk of the insect feeding occurred on the stems of the fruit cluster rather than on the fruit themselves. The possible presence of $X$. fastidiosa in the grape seed from such fruit was not addressed (23).

Although $X$. fastidiosa was found in peduncles of sweet oranges when the bacterium was first associated with the disease in 1990 (28), the colonization of the sweet orange fruit and seed by the pathogen has not received attention. The objectives of our research were to characterize the distribution of $X$. fastidiosa in various parts of sweet orange fruit and seeds and to determine whether the pathogen can be transmitted through seed to seedlings. 


\section{MATERIALS AND METHODS}

Grove history and collection of fruit and seed. The most economically important sweet orange cultivars in Brazil, 'Pera', 'Valencia', and 'Natal', were selected for study. All three cultivars were grafted on 'Rangpur' lime (Citrus limonia L.) rootstocks and had been planted in 1993 and 1994 in separate blocks of 2,700 or 2,800 trees in the region of Bebedouro, São Paulo, Brazil. More than $60 \%$ of the plants in each block had shown CVC leaf and fruit symptoms before these experiments were initiated in 1999. Three trees at CVC disease severity level 3, as well as three apparently healthy trees were selected from each cultivar. Disease severity level 3 means that all of the main branches show both leaf and fruit symptoms (2). Undersized fruit were harvested from the symptomatic trees. The apparently healthy trees did not have any CVC symptoms and were negative for $X$. fastidios $a$ in diagnostic tests of leaf petioles using polymerase chain reaction (PCR) (21). The fruit from the apparently healthy trees were normal in size.

More than 400 abnormally small fruits and another 400 apparently healthy fruit were harvested in August 1999 for extraction of seeds and detection of X. fastidiosa in fruits. The seeds, usually three to five per fruit, were removed from the fruit, washed three times in tap water, and dried for $24 \mathrm{~h}$ in shade at room temperature. Seeds were divided into lots and either sown in soil or set aside for dissection and assay for X. fastidiosa by PCR. Fruits not needed to provide seeds were stored at $4^{\circ} \mathrm{C}$ for 2 weeks until they were dissected and the internal tissues were assayed for $X$. fastidiosa by PCR (21).

Seed morphology, sowing, and germination. Three hundred seeds of each cultivar from CVC-affected fruits and another 300 seeds from apparently healthy fruits were examined visually for any abnormalities and then separated into lots of 100 seeds each (replicates), which were then weighed. The seeds were dissected into two parts, the embryos and the seed coats. Because it was difficult to completely separate the inner coat (tegma) from either the outer coat (testa) or embryo, portions of the inner coat (tegma) were included in both the outer coat (testa) and embryo samples. For seed germination tests and seedling analysis, four lots of 50 seeds each from CVC-affected fruit and another four lots of 50 seeds each from apparently healthy fruit of each cultivar were sown in 18-liter pots that contained commercial potting mix (Plantmax; Eucatex, São Paulo, Brazil). Pots were watered twice daily. The number of germinated seeds was recorded each day at 5:00 p.m. and tallied until 45 days, after which the remaining seeds did not germinate. Two months after sowing, 100 seedlings from seeds of CVC-affected fruits and another 100 seedlings from apparently healthy fruit were transplanted into 2-liter pots (15) for further growth and observation. Total DNA was extracted from the primary roots and aerial parts (leaves and stems) of the remaining seedlings and tested for the presence of $X$. fastidiosa by PCR (21). All plants were maintained in screen-protected greenhouses throughout the experiments to preclude unintended transmission of the pathogen by insect vectors. Analysis of variance was performed on the means and, when significant, was followed by a means comparison test (Tukey's test) using a confidence level of $P=0.05$.

Extraction of genomic DNA from sweet orange fruit. Five CVC-affected fruits and another five apparently healthy fruits of each cultivar were sampled for detection of $X$. fastidiosa. The fruits were separated into six parts: peduncle, peel, or pericarp, (including the exocarp or flavedo), the mesocarp or albedo, endocarp, septum, locular membrane, and central axis. Three 0.2-g samples were prepared as replications from each anatomical part per fruit for DNA extraction, for a total of 180 samples of fruit parts. An additional 100 seeds from CVC-affected fruits, and another 100 seeds from apparently healthy fruit of each of the three cultivars were used individually for detection for $X$. fastidi$o s a$. The seed coat (about $0.03 \mathrm{~g}$ ) and embryos (about $0.10 \mathrm{~g}$ ) from each seed were used separately for DNA extraction and PCR testing, for a total of 1,200 samples of seed parts.

Genomic DNA was prepared from fruit or seed with a modified CTAB (cetyltetramethyl ammonium bromide) procedure (29) as follows: $0.2 \mathrm{~g}$ of fruit tissue (for seeds, less than $0.2 \mathrm{~g}$ ) was placed in tubes with $1 \mathrm{ml}$ of phosphate buffered saline and homogenized with a Polytron blender (Pro Scientific, Monroe, CT). Extracts were filtered through four layers of cheesecloth and centrifuged for $5 \mathrm{~min}$ at $420 \times g$. The supernatant was transferred to a fresh tube and centrifuged for $20 \mathrm{~min}$ at $17,900 \times \mathrm{g}$. The pellet was resuspended in $250 \mu \mathrm{l}$ of $\mathrm{TE}$ buffer $(0.5 \mathrm{M}$ Tris- $\mathrm{HCl}, 0.5 \mathrm{M}$ EDTA, $\mathrm{pH}$ 8.0) containing $10 \% \mathrm{~N}$-lauryl sarcosine, proteinase K at $10 \mathrm{mg} / \mathrm{ml}$, and ribonuclease at $10 \mathrm{mg} / \mathrm{ml}$, and incubated for $1 \mathrm{~h}$ at $37^{\circ} \mathrm{C} . \mathrm{NaCl}(5 \mathrm{M}, 100 \mu \mathrm{l})$ was added to the solution, which was incubated for $10 \mathrm{~min}$ at $65^{\circ} \mathrm{C}$. A CTAB/ $\mathrm{NaCl}(50 \mu \mathrm{l})$ solution was added to the mixture and incubated for $20 \mathrm{~min}$ at $65^{\circ} \mathrm{C}$. Chloroform/isoamyl alcohol (24:1, vol/vol; $400 \mu \mathrm{l})$, was added and mixed thoroughly. The mixture was centrifuged for $5 \mathrm{~min}$ at $17,900 \times g$. The aqueous phase was transferred to a fresh tube, 0.6 volumes of isopropanol were added, and the mixture was incubated for $1 \mathrm{~h}$ at $-20^{\circ} \mathrm{C}$ and centrifuged for $15 \mathrm{~min}$ at $17,900 \times g$. The supernatant was removed and the pellet was washed with $500 \mu \mathrm{l}$ of $70 \%$ ethanol and centrifuged for $5 \mathrm{~min}$ at $10,600 \times g$. The supernatant was removed and the pellet was dried for $5 \mathrm{~min}$ in a vacuum. The pellet was dissolved in $20 \mu \mathrm{l}$ of TE buffer $(10 \mathrm{mM}$ Tris and $1 \mathrm{mM}$ EDTA) and stored at $-20^{\circ} \mathrm{C}$.

PCR. Standard PCR assays were performed with primers specific for $X$. fastidiosa, 272-1-int and 272-2-int (21), in a final reaction volume of $40 \mu \mathrm{l}$. The amplification program began with incubation at $94^{\circ} \mathrm{C}$ for 4 min followed by 35 cycles of $94^{\circ} \mathrm{C}$ for $1 \mathrm{~min}$, $64^{\circ} \mathrm{C}$ for $1 \mathrm{~min}$, and $72^{\circ} \mathrm{C}$ for $1.5 \mathrm{~min}$ followed by a final extension cycle of $10 \mathrm{~min}$ at $72^{\circ} \mathrm{C}$. PCR products were visualized by staining with ethidium bromide following electrophoresis through agarose gels. The expected amplification product was 472 bp (21).

Quantitative real-time PCR detection. The LightCycler instrument (Roche Diagnostics, Mannheim, Germany) was used to quantify $X$. fastidiosa cells in seeds. Hybridization probes (CVC1: 5'-GCC GCA AGA TGT TTC ATA G [FL-Q]-3'; and CVC2: 5'[AmC6+LCRed640] GAC ACC GTT TCA TGG ATG-[Phop-Q]$3^{\prime}$ ) were designed based on the sequence of the 472-bp PCR product of primers 272-1-int and 272-2-int (21). Each reaction was carried out in $18 \mu \mathrm{l}$ of PCR mixture containing LightCycler DNA master mix (consisting of Taq polymerase, PCR buffer, and dNTPs), $200 \mathrm{nM}$ primer 272-1-int, $200 \mathrm{nM}$ primer 272-2-int, $200 \mathrm{nM}$ probe $\mathrm{CVC} 1,400 \mathrm{nM}$ probe $\mathrm{CVC} 2$, and $2.5 \mathrm{mM} \mathrm{MgCl} 2$. The amplification program began with 1 cycle of primary denaturation at $95^{\circ} \mathrm{C}$ for $30 \mathrm{~s}$ followed by 45 cycles of $95^{\circ} \mathrm{C}$ for $0 \mathrm{~s}$ with a ramp rate of $20^{\circ} \mathrm{C} / \mathrm{s}, 58^{\circ} \mathrm{C}$ for $10 \mathrm{~s}$ with a ramp rate of $20^{\circ} \mathrm{C} / \mathrm{s}$, and $72^{\circ} \mathrm{C}$ for $20 \mathrm{~s}$ with a ramp rate of $20^{\circ} \mathrm{C} / \mathrm{s}$. The signal detection setting was $\mathrm{F} 2 / \mathrm{F} 1$, and the fluorescence gains were $\mathrm{F} 1=$ $1, \mathrm{~F} 2=15$, and $\mathrm{F} 3=30$. A standard curve was established using 10 -fold serial dilutions $\left(10^{0}-10^{-6}\right)$ of a colony of $X$. fastidiosa strain $9 \mathrm{a} 5 \mathrm{c}$ suspended in $100 \mu \mathrm{l}$ of water.

PCR product cloning and sequencing. The PCR product amplified using primer pair 272-1-int and 272-2-int was isolated and purified using the Geneclean Spin Kit (Qbiogene, Carlsbad, $\mathrm{CA}$ ), cloned into the TOPO TA cloning vector pCR2.1, and the resulting plasmids were introduced into One Shot TOP10 chemically competent Escherichia coli (Invitrogen, Carlsbad, CA) according to the manufacturer's instructions. Plasmid DNA was purified using the RPM kit (Qbiogene). DNA sequencing was done at the Genomics and Sequencing Laboratory, Auburn University, AL.

\section{RESULTS}

Presence of $X$. fastidiosa in fruit. The fresh weight of CVCaffected fruit of the three cultivars tested was about $25 \%$ less than 
that of normal healthy fruit. X. fastidiosa was detected by PCR (Fig. 1) in samples of peduncle, peel, endocarp, septum, locular membrane, and central axis of CVC-affected fruits of the three sweet orange cvs. Pera, Natal, and Valencia. Of the 15 symptomatic fruits analyzed, all samples from the peduncles and central axis septa contained $X$. fastidiosa DNA, based on PCR tests. Of the samples of fruit peels and endocarp, $80 \%$ were positive for the presence of $X$. fastidiosa DNA, as well as $50 \%$ of the samples prepared from locular membranes. X. fastidiosa was not detected in any parts of the fruits collected from apparently healthy trees of the three cultivars.

Seed symptoms. No discoloration, lesions, or spots were observed on seed collected from these CVC-affected fruit. No significant differences were observed between CVC-affected and apparently healthy fruit in either number of seeds per fruit or the ratio of normal to aborted seed (W.-B. Li, W. D. Pria, Jr., and P. M. Lacava, unpublished data). There was also no obvious difference in the weight of the seeds from the healthy and CVC-affected fruits or in the weight of the seed coats. However, the weight of embryos of the seeds from CVC-affected fruits was $25 \%$ less than those from healthy fruits (Table 1). The reduction of the fresh weight of the embryos was the only symptom observed in the seeds from CVC-affected fruits of the three cultivars.

Seed germination. Seeds from CVC-affected and healthy fruits started to germinate at the same time, 12 days after sowing (Fig. 2). However, the cumulative total of seeds germinated from CVCaffected fruits consistently lagged behind that of the seeds from healthy fruits through the entire germination period of 44 days. The germination rate for seeds from healthy fruits 33 days after sowing reached $100 \%$, but the final germination rate for seeds from CVC-affected fruits was only $91 \% 36$ days after sowing. There were no apparent differences in seed germination among the three sweet orange cultivars.

Presence of $\boldsymbol{X}$. fastidiosa in seeds. It was not possible to completely separate the inner coat (tegma) from either the outer coat (testa) or from cotyledons and embryos so portions of the inner seed coat (tegma) were present in both embryo and seed coat

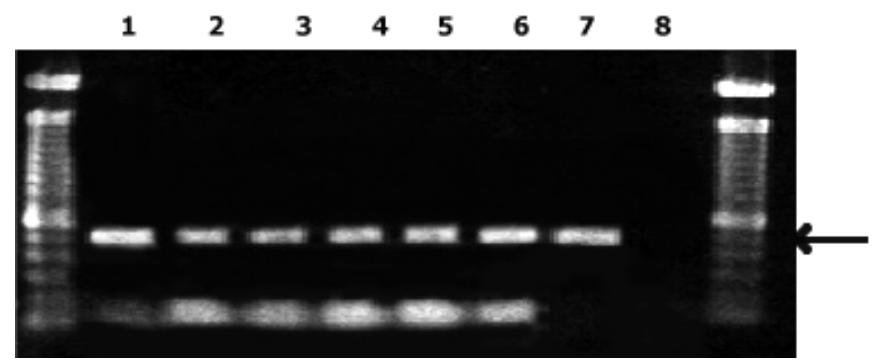

Fig. 1. Detection of Xylella fastidiosa in portions of sweet orange fruits assayed by polymerase chain reaction (PCR). Lane 1, peduncle; lane 2, exocarp; lane 3, mesocarp; lane 4, endocarp; lane 5, septa; lane 6, central axis; lane 7, X. fastidiosa strain 9a5c from culture in PW (5) medium; and lane 8 , central axis from healthy fruit as negative control. The outside lanes contain a 100-bp ladder as a size marker. The PCR product, indicated by the arrow, is $472 \mathrm{bp}$.

TABLE 1. Fresh weight in grams of 100 seeds from citrus variegated chlorosis (CVC)-affected and healthy sweet orange fruit ${ }^{\mathrm{x}}$

\begin{tabular}{lccccc}
\hline & \multicolumn{2}{c}{ Seed coat $^{\mathrm{y}}$} & & \multicolumn{2}{c}{ Embryo $^{\mathrm{z}}$} \\
\cline { 2 - 3 } \cline { 5 - 6 } Cultivar & Healthy & CVC-affected & & Healthy & CVC-affected \\
\hline Pera & 3.45 & 3.40 & & $11.01 \mathrm{a}$ & $8.84 \mathrm{~b}$ \\
Natal & 3.62 & 3.60 & & $11.35 \mathrm{a}$ & $9.12 \mathrm{~b}$ \\
Valencia & 3.50 & 3.42 & & $10.98 \mathrm{a}$ & $8.80 \mathrm{~b}$ \\
\hline
\end{tabular}

${ }^{x}$ Means followed by the same letter in each row are not different $(P<0.05)$ according to Tukey's test.

y Testa (outer coat), but includes some tegma (inner coat).

${ }^{\mathrm{z}}$ Includes cotyledons and some tegma (inner coat). samples as summarized in Table 2. X. fastidiosa was detected by PCR (Fig. 3) in 20 to $22 \%$ of the seed coat samples and in 15 to $16 \%$ of the embryo samples from seeds of CVC-affected fruits of the three sweet orange cultivars (Table 2). This difference was statistically significant, but no significant differences were observed for the presence of $X$. fastidiosa in seed among the three cultivars. $X$. fastidiosa was not detected in any part of the seeds from healthy fruits of the three sweet orange cultivars.

Presence of $X$. fastidiosa in seedlings. One month after sowing, 250 seedlings were evaluated by PCR for $X$. fastidiosa (Table 3). The bacterium was detected in seedlings from 'Pera', 'Natal', and 'Valencia' sweet orange obtained from seeds collected from CVC-affected fruits. Among the 59 positive seedlings, $X$. fastidiosa was detected in aerial parts of 51 seedlings, in the primary roots of 14 seedlings, and in both aerial parts and primary roots of 6 seedlings. $X$. fastidiosa was not detected in any seedling obtained from the seeds of healthy fruits from the three sweet orange cultivars.

Isolation of $X$. fastidiosa from seedlings and observation of CVC symptoms. Fastidious bacteria were isolated on PW (5) medium from 3-month-old PCR-positive seedlings of 'Pera', 'Natal', and 'Valencia' (Table 3). The identity of isolates as $X$. fastidiosa was confirmed by PCR (Fig. 3). CVC-like foliar symptoms were observed in some of the 4-month-old PCR-positive seedlings (five

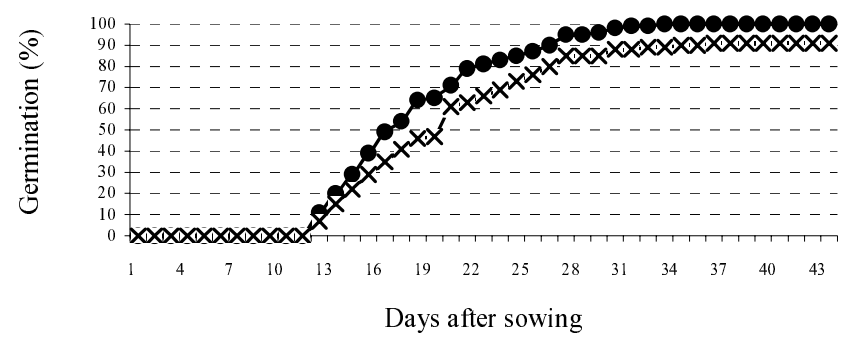

Fig. 2. Germination of seeds from apparently healthy and citrus variegated chlorosis (CVC)-affected 'Pera' sweet orange fruit: $\bullet$, apparently healthy fruit; and $\times$, CVC-affected fruit.

TABLE 2. Detection by polymerase chain reaction of Xylella fastidiosa in seeds from citrus variegated chlorosis (CVC)-affected sweet orange fruit ${ }^{\mathrm{x}}$

\begin{tabular}{lcc}
\hline Cultivar & Seed coat $^{\mathrm{y}}(\%)$ & Embryo $^{\mathrm{z}}(\%)$ \\
\hline Pera & 22.3 & 16 \\
Natal & 21.7 & 14.7 \\
Valencia & 20.3 & 15.3 \\
Means & 21.4 & 15.3 \\
\hline
\end{tabular}

${ }^{x}$ One hundred seeds were dissected and tested per cultivar.

${ }^{y}$ Testa (outer coat), but includes some tegma (inner coat).

${ }^{\mathrm{z}}$ Includes cotyledons and some tegma (inner coat).

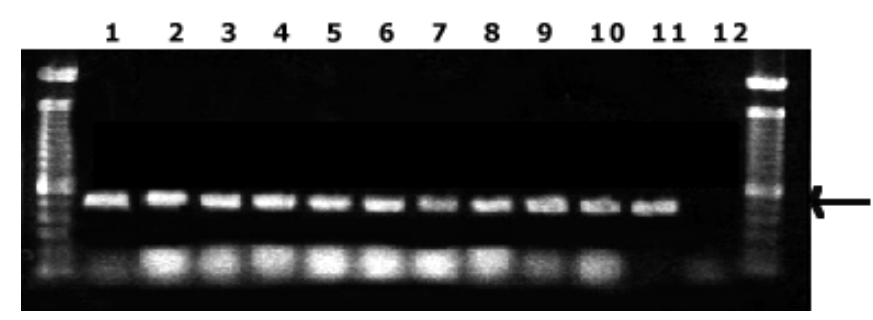

Fig. 3. Detection of Xylella fastidiosa in seed parts and seedlings and identification of isolates from seedlings as X. fastidiosa. Lanes 1 and 11, strain $9 \mathrm{a} 5 \mathrm{c}$ of $X$. fastidiosa from culture in PW (5) medium; lane 2, seed coat; lanes 3 and 4, embryos; lanes 5 to 7, in vitro isolates from 'Valencia', 'Natal', and 'Pera' seedlings, respectively; lanes 8 to 10, seedlings of 'Pera', 'Natal', and 'Valencia'; and lane 12, water. The outside lanes contain a 100-bp DNA ladder as a size marker. The polymerase chain reaction product, indicated by the arrow, is $472 \mathrm{bp}$. 
'Valencia', four 'Pera', and two 'Natal'). However, these symptoms disappeared 1 month later. Observation of further CVC symptom development was abruptly terminated when a tornado destroyed the greenhouse in September 2001.

DNA cloning and sequencing of $X$. fastidiosa. The products amplified by PCR from seeds of CVC-affected fruits of the three sweet orange cultivars (two per cultivar) were isolated from an agarose gel, purified, cloned, and sequenced. The sequences were compared with sequences in the NCBI GenBank database using BlastN. All of these sequences were identical and perfectly matched the corresponding sequence of strain $9 \mathrm{a} 5 \mathrm{c}$ of $X$. fastidiosa isolated from sweet orange twigs (31).

Quantification of $\boldsymbol{X}$. fastidiosa in seeds. Ten PCR-positive seed coats and embryos of each cultivar were subjected to quantitative PCR. A typical result is shown in Figure 4. The colony of $X$. fastidiosa used to establish the standard curve had about 200,000 live colony forming units, as determined by dilution plating onto PW plates. On the basis of this standard curve, our 2- $\mu$ l aliquots of extracts of seed coats or embryos from CVC-affected seed used in the Lightcycler reactions contained about 50 cells of $X$. fastidiosa (Fig. 4). Therefore, the 50- $\mu$ l extracts from seed coats or embryos each contained approximately 1,250 cells of $X$. fastidiosa, and a contaminated seed would have a minimum of 2,500 X. fastidiosa cells. There were no significant differences in number of $X$. fastidiosa cells among the seeds from the three sweet orange cultivars evaluated (data not shown). X. fastidiosa was not detected in extracts of seeds prepared from apparently healthy fruit (Fig. 4).

\section{DISCUSSION}

The closest relatives of $X$. fastidiosa are in the genus Xanthomonas (33). Some xanthomonads are known to infect and be transmitted by infected seed (19). However, the fact that X. fastidiosa is limited in plants to the xylem vessel elements has persuaded many researchers that transmission of $X$. fastidiosa by seed is impossible. We detected the bacterium using PCR in the peduncle as well as in the axial, dorsal and marginal bundles, and septa of diseased fruits from the three sweet orange cultivars tested.

$X$. fastidiosa was also detected in the outer coat (testa) of the seeds as well as in the embryos. The rate of seed infection by $X$. fastidiosa was as great as $22.3 \%$ for 'Pera' sweet orange in our analysis. The high rate of seed infection is consistent with $X$. fastidiosa spreading through the vascular system from the infected tree to the fruit and into the seed. In the work reported here, it was not possible to completely separate the inner seed coat (tegma) from the embryos (including cotyledons) or outer seed coat (testa) so the inner seed coat was present in portions of both the outer seed coat and embryo samples. Even with this caveat, our results clearly showed infection of the seed coat (testa plus tegma) with X. fastidiosa.

Although the mechanism is not certain, we have demonstrated that $X$. fastidiosa can be transmitted through seed to seedlings. We isolated the bacterium from seedlings and confirmed its identity as

TABLE 3. Detection of Xylella fastidiosa by polymerase chain reaction (PCR) and isolation in culture from sweet orange seedlings obtained from seeds extracted from citrus variegated chlorosis (CVC)-affected fruits

\begin{tabular}{lccccc}
\hline & \multirow{2}{*}{$\begin{array}{c}\text { No. of } \\
\text { plants }\end{array}$} & \multicolumn{4}{c}{ No. of positive reactions } \\
\cline { 3 - 6 } Cultivar & tested & Plants $^{z}$ & $\begin{array}{c}\text { Primary } \\
\text { root }\end{array}$ & $\begin{array}{c}\text { Aerial } \\
\text { parts }\end{array}$ & $\begin{array}{c}\text { Root and } \\
\text { aerial parts }\end{array}$ \\
\hline Pera & 87 & $14(16.1 \%) 2$ & 5 & 12 & 3 \\
Natal & 80 & $26(32.5 \%) 2$ & 6 & 22 & 2 \\
Valencia & 83 & $19(22.9 \%) 3$ & 3 & 17 & 1 \\
Totals & 250 & $59(23.6 \%) 7$ & $14(5.6 \%)$ & $51(20.4 \%)$ & $6(10.1 \%)$ \\
\hline
\end{tabular}

${ }^{\mathrm{z}}$ The first number is the number of positive PCR reactions, the number in parentheses is the percentage of PCR-positive seedlings, and the third number is the number of seedlings from which $X$. fastidiosa was isolated.
$X$. fastidiosa by sequence analysis of the PCR product. Of the 250 seedlings evaluated that were grown from seeds from CVC-affected fruits, 59 (23.6\%) were positive for X. fastidiosa (Table 3). Thus, the transmission is efficient, and the bacterium tends to appear first in the aerial parts of the developing seedlings, but is also detected in the developing primary root.

The results of limited quantitative real-time PCR testing showed that an infected sweet orange seed could have about 2,500 X. fastidiosa cells. Therefore, both standard PCR with specific primers and quantitative real-time PCR with specific hybridization probes can be used for detection of X. fastidiosa in citrus seed.

The vascular system and natural openings in seeds are the two most important entrances for seedborne pathogens (19). From the detailed descriptions of the sweet orange vascular system by Schneider (30), it is clear that the sweet orange seed is (i) abundantly endowed with xylem vessels which are, in turn, directly connected to the vascular system of the plant, (ii) the xylem vessels ramify throughout the seed coat, (iii) the vascular system is separated from the embryo only by a thin layer of cells in the chalaza, and (iv) the seed coat has a natural opening in it (the micropyle). Therefore, the conditions for seedborne infection by $X$. fastidiosa, a well-developed vascular system and an opening in the seed, are both met in sweet orange seeds.

There is no anatomical barrier that would prevent $X$. fastidiosa from spreading throughout the seed coat and into the chalazal end of the inner seed coat through vascular tissue. The vascular system ends at the vascular cap, where the nucellus is separated from the vascular cap only by the brown layer of chalaza, a thin layer of brown cells that also stain darkly in histological sections (30). The brown layer of the chalaza is not cutinized (7).

A great deal of ergastic materials must cross the chalaza to support the growth and development of the embryo, “....and the endosperm must act as a conductive tissue, with the seed vascular bundle, the plexus of vascular tissue in the chalaza, the brown layer in the chalaza, and the intervening nucellus figuring very importantly in the transport of food" (30). "Cells of the nucellusespecially at its base-are elongated in such a way as to be adapted to transport" (30). Perhaps X. fastidiosa can be carried into the developing embryo along with these ergastic materials.

Alternatively, in other instances of seed transmission of pathogens, transmission from the adhering infected seed coat to the cotyledons or to the embryos of the developing seedlings may occur during the process of germination and emergence (32). The sweet orange embryos are exposed through the natural slit-shaped openings in the integuments at the opposite end of the seed, the micropyle (30). However, this scenario does not explain how $X$.

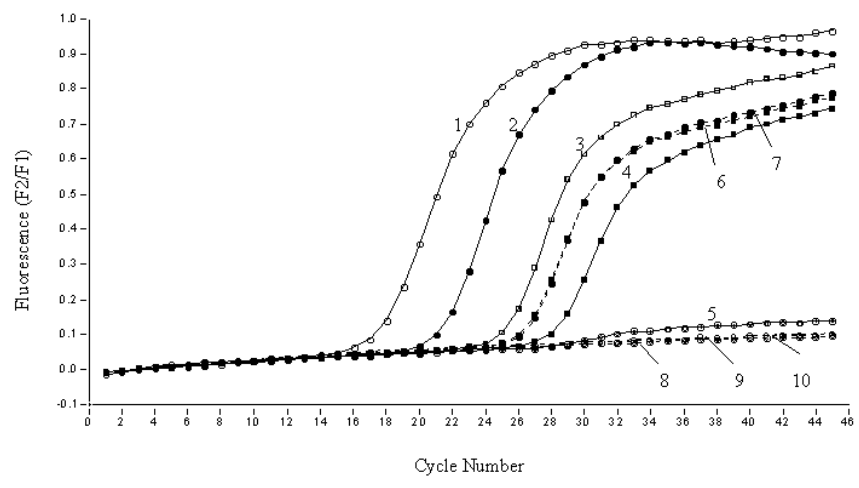

Fig. 4. Real-time amplification plot of Xylella fastidiosa target in infected seed parts. Curves 1 to 5,10 -fold dilution series of strain $9 \mathrm{a} 5 \mathrm{c}$ of $X$. fastidiosa cultured in PW (5) medium; the reactions contained $4 \times 10^{4}$ to 4 cells, respectively. Curve 6 , seed coat from seed of a citrus variegated chlorosis (CVC)-affected fruit of 'Pera' sweet orange; curve 7, embryo from seed of a CVC-affected fruit of 'Pera' sweet orange; curve 8, seed coat from seed of a healthy fruit of 'Pera' sweet orange; curve 9, embryo from seed of a healthy fruit of 'Pera' sweet orange; and curve 10, water only. 
fastidiosa would gain entry into the xylem vessels. The details of this infective process deserve further study.

$X$. fastidiosa is a xylem-limited bacterium and, to our knowledge, this is the first report of its presence in seeds and of its transmission to seedlings through seeds. Although citrus scion cultivars are propagated by bud grafting from mother trees on rootstocks, the rootstocks are typically seedlings of specific citrus species or cultivars. Some citrus rootstocks are resistant, some are tolerant, and others are susceptible to the CVC disease; $X$. fastidiosa can survive in many commercial citrus rootstocks (14). 'Rangpur' lime is the key rootstock for citriculture in Brazil, where more than $90 \%$ of citrus trees are grafted onto this rootstock. 'Rangpur' lime rootstock mother trees may be grown in orchards in the presence of high disease and insect pressure. 'Rangpur' lime does not show foliar symptoms of the disease, and no screening of the fruit and seeds are done for $X$. fastidiosa. It may be possible for seed from asymptomatic 'Rangpur' lime trees to carry $X$. fastidiosa. Although we did not study seed of 'Rangpur' lime in this work, this should be done, and it would be wise to provide greater protection for rootstock mother trees.

The infected fruit selected for this study were grossly symptomatic for CVC and weighed $25 \%$ less than the healthy fruit used for comparisons. Thus, these fruits can be easily avoided when fruit are harvested for seed collection. Sweet orange seed did not show obvious symptoms or signs of infection by the pathogen. The possibility that seed from normal-sized fruit from infected trees may also transmit $X$. fastidiosa to seedlings should also be evaluated.

The experimental transmission efficiency of the CVC disease is low, less than $5 \%$ using sharpshooters (26) and $3 \%$ by common bud grafting with contaminated materials (13). However, disease incidence increases rapidly under field conditions (20). The possibility of transmission of $X$. fastidiosa through citrus rootstock seedlings may require a reassessment of disease management strategies.

These findings should alert researchers to the possible seed transmission of other strains of $X$. fastidiosa. We note that coffee plantations in Brazil suffer from a widespread and serious disease, coffee leaf scorch or Requeima do café, caused by strains of $X$. fastidiosa (6). The coffee strains of $X$. fastidiosa are closely related to the citrus strains $(25,27)$, and indeed, the citrus strains can reproduce the coffee disease following experimental inoculations (16). In Brazil, coffee is grown either from seed or from grafted plants in which both the scion and rootstock have been grown from seed. The possibility that $X$. fastidiosa can be transmitted through coffee seed should be investigated.

\section{ACKNOWLEDGMENTS}

We thank P. I. Costa, D. C. Teixeira, V. S. Miranda, F. J. B. Francischini, and E. O. Pereira for assistance in PCR assays.

\section{LITERATURE CITED}

1. Aldrich, J. H., Gould, A. B., and Martin, F. G. 1992. Distribution of Xylella fastidiosa within roots of peach. Plant Dis. 76:885-888.

2. Anonymous. 2000. CVC: Sintomas estao mais graves. Revista Fundecitrus 99:8-9.

3. Brlansky, R. H., Davis, C. L., Timmer, L. W., Howd, D. S., and Contreras, J. 1991. Xylem-limited bacteria in citrus from Argentina with symptoms of citrus variegated chlorosis. (Abstr.) Phytopathology 81:1210.

4. Chang, C. J., Garnier, M., Zreik, L., Rossetti, V., and Bové, J. M. 1993. Culture and serological detection of the xylem-limited bacterium causing citrus variegated chlorosis and its identification as a strain of Xylella fastidiosa. Curr. Microbiol. 27:137-142.

5. Davis, M. J., French, W. J., and Schaad, N. W. 1981. Axenic culture of the bacteria associated with Phony disease of peach and plum leaf scald. Curr. Microbiol. 6:309-314.

6. de Lima, J. E. O., Miranda, V. S., Hartung, J. S., Brlansky, R. H., Coutinho, A., Roberto, S. R., and Carlos, E. F. 1998. Coffee leaf scorch bacterium: Axenic culture, pathogenicity, and comparison with Xylella fastidiosa of Citrus. Plant Dis. 82:94-97.
7. Esau, K. 1965. Plant Anatomy. 2nd ed. John Wiley \& Sons, New York.

8. Gould, A. B., French, W. J., Aldrich, J. H., Brodbeck, B. V., Mizell, R. F. and Andersen, P. C. 1991. Rootstock influence on occurrence of Homalodisca coagulata, peach xylem fluid amino acids, and concentrations of Xylella fastidiosa. Plant Dis. 75:767-770.

9. Guilhabert, M. R., Hoffman, L. M., Mills, D. A., and Kirkpatrick, B. C. 2001. Transposon mutagenesis of Xylella fastidiosa by electroporation of Tn5 synaptic complexes. Mol. Plant-Microbe Interact. 14:701-706.

10. Hartung, J. S., Beretta, J., Brlansky, R. H., Spisso, J., and Lee, R. F. 1994. Citrus variegated chlorosis bacterium: Axenic culture, pathogenicity, and serological relationships with other strains of Xylella fastidiosa. Phytopathology 84:591-597.

11. He, C. X., Li, W. B., Ayres, A. J., Hartung, J. S., Miranda, V. S., and Teixera, D. C. 2000. Distribution of Xylella fastidiosa in citrus rootstocks and transmission of citrus variegated chlorosis between sweet orange plants through natural root grafts. Plant Dis. 84:622-626.

12. Hendson, M., Purcell, A. H., Chen, D., Smart, C., Guilhabert, M., and Kirkpatrick, B. 2001. Genetic diversity of Pierce's disease strains and other pathotypes of Xylella fastidiosa. Appl. Environ. Microbiol. 67:895903.

13. Li, W. B., Donadio, L. C., Beretta, M. J. G., Rosetti, V., and Sempionato, O. R. 1997. Practical methods of resistance evaluation of citrus varieties to citrus variegated chlorosis. Proc. Int. Soc. Citricult. I:276-279.

14. Li, W. B., Donadio, L. C., Stuchi, E. S., Beretta, M. J. G., Rossetti, V., Sempionato, O. R., Lemos, E. G. M., and Coutinho, A. 1997. Seedling resistance of 20 citrus rootstocks to citrus variegated chlorosis. Proc. Int. Soc. Citricult. I:283-285.

15. Li, W. B., Fernandes, N. G., Miranda, V. S., Teixera, D. C., Ayres, A. J., Garnier, M., and Bové, J. M. 1999. A triply cloned strain of Xylella fastidiosa multiplies and induces symptoms of citrus variegated chlorosis in sweet orange. Curr. Microbiol. 39:106-108.

16. Li, W.-B., Pria, W. D., Jr., Teixera, D. C., Miranda, V. S., Ayres, A. J., Franco, C. F., Costa, M. G., He, C.-X., Costa, P. I., and Hartung, J. S. 2001. Coffee leaf scorch caused by a strain of Xylella fastidiosa from citrus. Plant Dis. 85:501-505.

17. Lopes, S. A., Ribeiro, D. M., Roberto, P. G., Franca, S. C., and Santos, J. M. 2000. Nicotiana tabacum as an experimental host for the study of plant-Xylella fastidiosa interactions. Plant Dis. 84:827-830.

18. Monteiro, P. B., Renaudin, J., Jagoueix-Eveillard, S., Ayres, A. J., Garnier, M., and Bové, J. M. 2001. Madagascar periwinkle (Catharanthus roseus): An experimental host plant for the citrus strain of Xylella fastidiosa. Plant Dis. 85:246-251.

19. Neergaard, P. 1977. Seed Pathology, Vol. 1. John Wiley \& Sons, New York.

20. Nelson, S. C. 1996. A simple analysis of disease foci. Phytopathology 86:332-339.

21. Pooler, M. R., and Hartung, J. S. 1995. Specific PCR detection and identification of Xylella fastidiosa strains causing citrus variegated chlorosis. Curr. Microbiol. 31:377-381.

22. Purcell, A. H., and Hopkins, D. L. 1996. Fastidious, xylem limited plant pathogens. Annu. Rev. Phytopathol. 34:131-151.

23. Purcell, A. H., and Saunders, S. 1995. Harvested grape clusters as inoculum for Pierce's disease. Plant Dis. 79:190-192.

24. Qin, X., and Hartung, J. S. 2001. Construction of a shuttle vector and transformation of Xylella fastidiosa with plasmid DNA. Curr. Microbiol. 43:158-162.

25. Qin, X., Miranda, V. S., Machado, M. A., Lemos, E. G. M., and Hartung, J. S. 2001. An evaluation of the genetic diversity of Xylella fastidiosa isolated from diseased citrus and coffee in São Paulo, Brazil. Phytopathology 91:599-605.

26. Roberto, S., Coutinho, A., De Lima, J., Miranda, V., and Carlos, E. 1996. Transmission of Xylella fastidiosa by the sharpshooters Dilobopterus costalimai, Acrogonia terminalis, and Oncometopia fascialis (Homoptera: Cicadellidae) in citrus. Fitopatol. Bras. 21:517-518.

27. Rosato, Y. B., Neto, J. R., Miranda, V. S., Carlos, E. F., and Manfio, G. P. 1998. Diversity of a Xylella fastidiosa population isolated from Citrus sinensis affected by citrus variegated chlorosis in Brazil. System. Appl. Microbiol. 21:593-598.

28. Rosetti, V., Garnier, M., Bové, J. M., Beretta, M. J., Teixeira, A. R. R., Quaggio, J. A., and DeNegri, J. D. 1990. Presence de bacteries dan le xylem d'orangers atteint de chlorose variegee une nouvelle maladie des agrumes au Brazil. C.R. Acad. Sci. Paris 310:345-349.

29. Sarghai-Maroof, M. A., Soliman, K. M., Jorgenson, R. A., and Allard, R. W. 1984. Ribosomal DNA spacer-length polymorphisms in barley: Mendelian inheritance, chromosomal location and population dynamics. Proc. Natl. Acad. Sci. USA 81:8014-8018.

30. Schneider, H. 1968. The anatomy of citrus. Pages 1-85 in: The Citrus Industry, vol. 2. W. Reuther, L. D. Batchelor, and H. J. Webber, eds. University of California, Berkeley. 
31. Simpson, A. J. G., Reinach, F. C., Arruda, P., Abreu, F. A., Acencio, M., Alvarenga, R., Alves, L. M., Araya, J. E., Baia, G. S., Baptista, C. S., Barros, M. H., Bonaccorsi, E. D., Bordin, S., Bove, J. M., Briones, M. R., Bueno, M. R., Camargo, A. A., Camargo, L. E., Carraro, D. M., Carrer, H., Colauto, N. B., Colombo, C., Costa, F. F., Costa, M. C., Costa-Neto, C. M., Coutinho, L. L., Cristofani, M., Dias-Neto, E., Docena, C., El-Dorry, H., Facincani, A. P., Ferreira, A. J., Ferreira, V. C., Ferro, J. A., Fraga, J. S., Franca, S. C., Franco, M. C., Frohme, M., Furlan, L. R., Garnier, M., Goldman, G. H., Goldman, M. H., Gomes, S. L., Gruber, A., Ho, P. L., Hoheisel, J. D., Junqueira, M. L., Kemper, E. L., Kitajima, J. P., Krieger, J. E., Kuramae, E. E., Laigret, F., Lambais, M. R., Leite, L. C., Lemos, E. G., Lemos, M. V., Lopes, S. A., Lopes, C. R., Machado, J. A., Machado, M. A., Madeira, A. M., Madeira, H. M., Marino, C. L., Marques, M. V., Martins, E. A., Martins, E. M., Matsukuma, A. Y., Menck, C. F., Miracca, E. C., Miyaki, C. Y., Monteriro-Vitorello, C. B., Moon, D. H., Nagai, M. A., Nascimento, A. L., Netto, L. E., Nhani, A., Jr., Nobrega, F. G., Nunes, L. R., Oliveira,
M. A., de Oliveira, M. C., de Oliveira, R. C., Palmieri, D. A., Paris, A., Peixoto, B. R., Pereira, G. A., Pereira, H. A., Jr., Pesquero, J. B., Quaggio, R. B., Roberto, P. G., Rodrigues, V., de M Rosa, A. J., de Rosa, V. E., Jr., de Sa, R. G., Santelli, R. V., Sawasaki, H. E., da Silva, A. C., da Silva, A. M., da Silva, F. R., da Silva, W. A., Jr., da Silveira, J. F., Silvestri, M. L., Siqueira, W. J., de Souza, A. A., de Souza, A. P., Terenzi, M. F., Truffi, D., Tsai, S. M., Tsuhako, M. H., Vallada, H., Van Sluys, M. A., Verjovski-Almeida, S., Vettore, A. L., Zago, M. A., Zatz, M., Meidanis, J., and Setubal, J. C. 2000. The genome sequence of the plant pathogen Xylella fastidiosa. Nature 406:151-157.

32. Taylor, J. D., Dudley, C. L., and Pressley, L. 1979. Studies of halo blight seed infection and disease transmission in dwarf beans. Ann. Appl. Biol. 93:267-277.

33. Wells, J. M., Raju, B. C., Hung, H.-Y., Weisburg, W. G., Mandelco-Paul, L., and Brenner, D. J. 1987. Xylella fastidiosa gen. nov., sp. nov: Gramnegative, xylem limited, fastidious plant bacteria related to Xanthomonas spp. Int. J. System. Bacteriol. 37:136-143. 